WITOLD PŁOWIEC

\title{
GWARANCJE ZASADY NADRZĘDNOŚCI KONSTYTUCJI
}

I. Zasada nadrzędności Konstytucji została wyrażona w art. 8 ust. 1 Konstytucji Rzeczypospolitej Polskiej z 2 kwietnia 1997 r. ${ }^{1}$, który stanowi, że „Konstytucja jest najwyższym prawem Rzeczypospolitej Polskiej”. Przepis ten nie jest jednak jedyną wypowiedzią świadczaca o tym, że Konstytucja jest szczególnym źródłem prawa. Już we wstępie jej twórcy wskazali, że „ustanawiamy Konstytucję Rzeczypospolitej Polskiej jako prawa podstawowe dla państwa", wymienili Konstytucję jako pierwszą w katalogu źródeł powszechnie obowiązującego prawa Rzeczypospolitej Polskiej (art. 87 ust. 1), nadali jej status wzorca kontroli dla: ustaw i umów międzynarodowych (art. 188 pkt 1), innych aktów normatywnych (art. 79 ust. 1, art. 186 ust. 2 i art. 193), przepisów prawa wydawanych przez centralne organy państwowe (art. 188 pkt 3) oraz celów lub działalności partii politycznych (art. 188 pkt 4). Warto też zwrócić uwagę, na to, że zmiana Konstytucji może być dokonana tylko w taki sposób, w jaki ona przewiduje (art. 235).

II. Treść zasady nadrzędności Konstytucji nie należy sprowadzać tylko do przyznania jej najwyższej mocy prawnej w polskim systemie prawa. W art. 8 ust. 1 Konstytucji nie użyto zwrotu „najwyższa moc prawna”, ale „najwyższe prawo Rzeczypospolitej Polskiej”. Zwrot ten należy rozumieć szeroko jako odnoszący się zarówno do sfery tworzenia prawa, jak i jego stosowania. Zasada nadrzędności Konstytucji wyznacza miejsce tego aktu w hierarchicznie zbudowanym systemie prawa oraz podstawy kompetencyjne, treściowe i aksjologiczne porządku prawnego. W systemie prawa nie może być aktów normatywnych, które zawierałyby normy o mocy wyższej albo równej normom konstytucyjnym. Normy o niższej mocy prawnej (podkonstytucyjne) nie moga ani zmieniać, ani uchylać norm wyrażonych w Konstytucji. Konstytucja udziela kompetencji prawotwórczych określonym podmiotom, determinuje treść norm o niższej mocy prawnej i wyraża wartości, które mają być realizowane czy chronione w porządku prawnym.

1. W ujęciu dyrektywalnym zasada nadrzędności Konstytucji nakazuje realizowanie norm konstytucyjnych (aspekt pozytywny) i zakazuje zachowań niezgodnych z normami konstytucyjnymi (aspekt negatywny). W odniesieniu do tworzenia prawa normy podkonstytucyjne muszą być spójne i zupełne z normami konstytucyjnymi. Prawodawca ma zatem obowiązek tworzyć normy podkonstytucyjne w taki sposób, by były one zgodne z normami kon-

${ }^{1}$ Dz. U. Nr 78, poz. 483 ze zm. (dalej jako: Konstytucja, ustawa zasadnicza). 
stytucyjnymi i urzeczywistniały je w możliwie najpełniejszy sposób. Podobnie w odniesieniu do stosowania prawa: rozstrzygnięcia podjęte na podstawie Konstytucji muszą być zgodne z jej normami i w możliwe najwyższym stopniu je urzeczywistniać ${ }^{2}$.

2. Przepisy konstytucyjne często zbudowane są ze zwrotów wysoce niedookreślonych i przez to nieostrych. Stąd ich interpretacja nie jest łatwym zadaniem. „Dobro wspólne”, „państwo prawne”, „zasady sprawiedliwości społecznej”, „przyrodzona i nienaruszalna godność człowieka”, „wolność człowieka” to tylko przykłady takich zwrotów, których treść jest sporna i zależna od akceptowanych założeń o charakterze filozoficznym, politycznym czy religijnym. Twórcy Konstytucji świadomi tej specyfiki jej przepisów w wielu miejscach odsyłają do ustaw, które mają określić wyjątki, zasady, tryb, przypadki, ograniczenie - innymi słowy niezbędne doprecyzowania. Zasada nadrzędności Konstytucji nakłada zatem obowiązek ustanowienia takich ustaw, które zapewnia, że przepisy konstytucyjne nie będą wyrażały nierealnych albo pustych deklaracji. Konstytucja nie jest uroczystą deklaracja, ale zbiorem norm, które wyznaczają określone zachowania. Inna sprawa, że Konstytucja może w zbyt wielu przepisach odsyła do ustaw czy wyraża normy programowe, które $\mathrm{w}$ praktyce $\mathrm{w}$ zasadzie sa nieegzekwowalne, a przez to narażone na zarzut stwarzania fikcji (pustosłowia) .

3. Zasada nadrzędności Konstytucji jest konfrontowana z zasadą pierwszeństwa prawa Unii Europejskiej. Zasada pierwszeństwa prawa Unii Europejskiej (UE) wobec prawa państw członkowskich jest wytworem orzecznictwa Trybunału Sprawiedliwości Unii Europejskiej (TSUE) ${ }^{4}$. W myśl tej zasady w wypadku kolizji między normą prawa UE a normą prawa krajowego zastosowanie znajdzie norma prawa Unii, a norma prawa krajowego zostanie pominięta. Zasada pierwszeństwa prawa UE wobec prawa państw członkowskich ma charakter zupełny, ponieważ dotyczy wszystkich norm prawa krajowego, w tym również norm konstytucyjnych ${ }^{5}$.

${ }^{2}$ Por. P. Tuleja, Stosowanie Konstytucji RP w świetle zasady jej nadrzędności (wybrane problemy), Kraków 2003, s. 53-62; K. Działocha, uwagi do art. 8, w: L. Garlicki, M. Zubik (red.), Konstytucja Rzeczypospolitej Polskiej. Komentarz, t. 1, Warszawa 2016, s. 258-281; P. Tuleja, uwagi do art. 8, w: M. Safjan, L. Bosek (red.), Konstytucja RP, t. 1: Komentarz do art. 1-86, Warszawa 2016, s. 307-325.

${ }^{3}$ Zob. T. Gizbert-Studnicki, A. Grabowski, Normy programowe w konstytucji, w: J. Trzciński (red.), Charakter i struktura norm konstytucji, Warszawa 1997, s. 95-113.

${ }_{4}$ Zob. np. wyroki TSUE z: 15 lipca 1964 r. w sprawie 6/64, Flaminio Costa przeciwko E.N.E.L.; 17 grudnia 1970 r. w sprawie 11/70, Internationale Handelsgesellschaft mbH przeciwko Einfuhrund Vorratsstelle für Getreide und Futtermittel; 9 marca 1978 r. w sprawie 106/77, Amministrazione delle Finanze dello Stato przeciwko Simmenthal. Szerzej na ten temat zob. S. Biernat, Prawo Unii Europejskiej a prawo państw członkowskich, w: J. Barcz (red.), Prawo Unii Europejskiej. Zagadnienia systemowe. Prawo materialne i polityki, Warszawa 2006, s. I-254-I-271.

${ }^{5}$ Zob. np. wyroki TSUE z: 11 stycznia 2000 r. w sprawie C-285/98, Tanja Kreil przeciwko Niemcom; 19 listopada 2009 r. w sprawie C-314/08, Krzysztof Filipiak przeciwko Dyrektorowi Izby Skarbowej w Poznaniu; 8 września 2010 r. w sprawie C-409/06, Winner-Wetten. GmbH przeciwko Bürgermeisterin der Stadt Bergheim. 
Trybunał Konstytucyjny (TK), wypowiadając się o zasadzie nadrzędności Konstytucji w kontekście przystapienia Polski do UE, zwrócił uwagę, że prawo Unii nie jest prawem w pełni zewnętrznym w stosunku do państwa polskiego. W części stanowiącej prawo traktatowe powstaje ono przez akceptowanie traktatów zawartych przez wszystkie państwa członkowskie. W części zaś stanowiącej prawo pochodne kreowane jest ono przy udziale przedstawicieli rządów państw członkowskich - w Radzie Unii Europejskiej oraz przedstawicieli obywateli europejskich - w Parlamencie Europejskim. Ustrojodawca uznał wieloskładnikowy system prawa obowiąujący w Polsce, czemu wyraz daja liczne unormowania konstytucyjne: art. 9, art. 87 ust. 1 oraz art. 90-91. Polska Konstytucja oraz prawo UE oparte sa na tym samym zespole wspólnych wartości wyznaczających naturę demokratycznego państwa prawa oraz katalog i treść praw podstawowych. Ewentualne kolizje między normami konstytucyjnymi a normami UE powinny być zatem uzgadniane w procesie „przyjaznej wykładni”. Wykładnia „przyjazna dla prawa UE" ma jednak swoje granice. W żadnej sytuacji nie może ona prowadzić do rezultatów sprzecznych z treścią norm konstytucyjnych i niemożliwych do uzgodnienia z minimum funkcji gwarancyjnych, realizowanych przez Konstytucję.

W ocenie TK nie można jednak wykluczyć wystapienia nieusuwalnej sprzeczności pomiędzy normą Konstytucji a normą prawa UE. W takiej sytuacji możliwe są trzy rozwiązania: zmiana Konstytucji albo zmiana prawa UE, albo wystapienie z UE.

Zasada pierwszeństwa prawa UE nie uchyla zatem zasady nadrzędności Konstytucji w polskim porządku prawnym. W szczególności zasada nadrzędności Konstytucji w obszarze suwerenności Rzeczypospolitej Polskiej przejawia się w następujący sposób.

Po pierwsze, proces integracji europejskiej jest unormowany w Konstytucji i musi być zachowany przez polskie organy władzy publicznej dla ważnego i skutecznego przekazania kompetencji w niektórych sprawach organom unijnym przez Rzeczpospolita.

Po drugie, do kompetencji TK należy kontrola zgodności Traktatu akcesyjnego oraz aktów stanowiących jego integralne składniki z Konstytucją. Kontrola ta została oparta na tych samych zasadach, na jakich TK może orzekać o zgodności z Konstytucją ratyfikowanych umów międzynarodowych.

Po trzecie, sprzeczność między normą konstytucji a normą prawa UE nie może być rozwiązywana przez uznanie nadrzędności normy prawa UE wobec normy konstytucyjnej, stwierdzenie utraty mocy obowiązującej normy konstytucyjnej i zastapienia jej normą prawa UE, czy też ograniczenie zakresu stosowania normy konstytucyjnej do obszaru, który nie został objęty regulacja prawa UE. W takiej sytuacji suwerenny polski ustrojodawca zachowuje prawo samodzielnego zadecydowania o sposobie rozwiązania tej sprzeczności, w tym również o celowości ewentualnej zmiany samej Konstytucji ${ }^{6}$.

${ }^{6}$ Zob. wyroki TK z: 11 maja 2005 r., K 18/04, OTK ZU-A 2005, nr 5, poz. 49; 24 listopada 2010 r., K 32/09, OTK ZU-A 2010, nr 9, poz. 108. 
4. Nadanie Konstytucji cechy nadrzędności podkreśla jej znaczenie w porządku prawnym. Konstytucja jest bowiem umową społeczną zawartą pomiędzy sprawujaccymi władzę (rządzącymi) i podlegajaccymi tej władzy (rządzonymi). Tak rozumiana konstytucja chroni obywateli przed sprawującymi władzę, wyznaczając nieprzekraczalne granice dla władzy państwowej. Sposób zorganizowania państwa i jego organów, zakres ich kompetencji i relacje między nimi we współczesnych wspólnotach państwowych kultury wyrosłej z filozofii greckiej, prawa rzymskiego i chrześcijaństwa podporządkowany jest ochronie praw człowieka. W takim ujęciu nie ma konfliktu pomiędzy konstytucja - statutem organizacyjnym dla państwa i konstytucją - kartą praw człowieka. Wszystkie bowiem regulacje konstytucyjne maja na celu zabezpieczenie rządzonych przed rządzaccymi. Jest zatem konstytucja wyrazem braku zaufania dla władzy państwowej, której ufać zresztą jest niebezpiecznie, czego dowodzi historia. „Każda władza deprawuje, a władza absolutna deprawuje absolutnie” - zauważył w XIX w. Lord Acton i można podać wiele przykładów na prawdziwość tego stwierdzenia. Kto, jeśli nie sprawujący władzę odpowiedzialni są za mordy niewinnych istnień ludzkich, tortury i prześladowania. Wydaje się, że w tym miejscu świata, w Europie, w której narodziły się dwa zbrodnicze totalitaryzmy, powinniśmy szczególnie być uwrażliwieni na respektowanie przez władze norm konstytucyjnych.

Stąd faktyczne zapewnienie konstytucji nadrzędności jest istotne dla ochrony nas, ludzi, przed nieliczną garstką tych, którzy sprawują władzę, nawet jeżeli ich wybraliśmy w demokratycznych wyborach. Nikt bowiem nie może być pewien, czy powierzonej władzy nie wykorzystają przeciwko nam.

III. Konstytucja zawiera liczne gwarancje swojej nadrzędności. Zaliczyć do nich można w szczególności: procedurę zmiany Konstytucji, odpowiedzialność przed Trybunałem Stanu (TS), kontrolę konstytucyjności prawa przez Trybunał Konstytucyjny, bezpośrednie stosowanie Konstytucji oraz ślubowania składane przez parlamentarzystów, Prezydenta i członków Rady Ministrów.

1. Procedura zmiany Konstytucji uregulowana jest w jej art. 235, a celem tej procedury jest zabezpieczenie ustawy zasadniczej ${ }^{7}$. Jak już wskazałem, zasada nadrzędności Konstytucji zakazuje, by normy o niższej mocy prawnej (podkonstytucyjne) zmieniały lub uchylały normy wyrażone w ustawie zasadniczej. Gdyby nie było szczególnej procedury zmiany Konstytucji należałoby przyjąć, że w ogóle nie można jej zmieniać albo też jej zmiana następuje w procedurze przewidzianej dla uchwalenia ustawy. Jedno i drugie rozwiazanie byłoby dysfunkcjonalne. Pierwsze ze względu na to, że wraz ze zmianami społecznymi, gospodarczymi czy politycznymi zmiana ustawy zasadniczej może być konieczna. Drugie, ponieważ każda ustawa niezgodna z Konstytucją ozna-

${ }^{7}$ Zob. np. W. Sokolewicz, uwagi do art. 235, w: L. Garlicki (red.), Konstytucja Rzeczypospolitej Polskiej. Komentarz, t. 2, Warszawa 2001, s. 1-75; P. Tuleja, B. Szczurowski, uwagi do art. 235, w: M. Safjan, L. Bosek (red.), Konstytucja RP, t. 2: Komentarz do art. 87-243, Warszawa 2016, s. $1638-1663$. 
czałaby zmianę ustawy zasadniczej, co powodowałoby fikcję konstytucyjnych gwarancji ochrony praw człowieka.

Wymóg, by zmiana Konstytucji uchwalona została przez Sejm większościa co najmniej ${ }^{2} / 3$ głosów w obecności co najmniej połowy ustawowej liczby posłów oraz Senat bezwzględną większością głosów w obecności co najmniej połowy ustawowej liczby senatorów (art. 235 ust. 4) - zapewnia konieczność uzyskania konsensusu w parlamencie między konkurującymi partiami politycznymi. Choć nie można wykluczyć sytuacji, gdy jedna partia polityczna zdobywa tyle mandatów, że może samodzielnie zmienić Konstytucję, to nieliczenie się z opozycją nie przyczyni się z pewnością do wzmocnienia poparcia zmian w Konstytucji przez społeczeństwo i ich legitymizacji.

Zaangażowanie społeczeństwa w procedurę zmiany Konstytucji jest przewidziane, w wypadku gdy zmiana Konstytucji dotyczy przepisów rozdziałów I, II lub XII Konstytucji (art. 235 ust. 6). Możliwe jest wtedy bowiem przeprowadzenie referendum zatwierdzającego zmianę ustawy zasadniczej. Referendum to musi być przeprowadzone, gdy łącznie zostaną spełnione trzy warunki:

- po pierwsze, zmiana Konstytucji będzie dotyczyła przepisów rozdziałów I, II lub XII Konstytucji;

- po drugie, któryś z podmiotów mających prawo inicjowania zmiany Konstytucji (co najmniej 1/5 ustawowej liczby posłów, Senat lub Prezydent) wystapi do Marszałka Sejmu z wnioskiem o jego przeprowadzenie,

- po trzecie, wniosek o przeprowadzenie referendum zostanie wniesiony w terminie 45 dni od dnia uchwalenia ustawy o zmianie Konstytucji przez Senat.

Ograniczenie przeprowadzenia referendum zatwierdzającego zmianę Konstytucji do jej trzech rozdziałów, tzn. I, II i XII, nie jest przypadkowe. Twórcy Konstytucji wskazali te rozdziały, ponieważ to właśnie w nich zamieszczone sa regulacje dotyczące: zasad prawa (rozdział I) oraz wolności, praw i obowiązków człowieka i obywatela (rozdział II). Wymienienie rozdziału XII regulującego procedurę zmiany Konstytucji ma charakter instrumentalny, ponieważ służy zabezpieczeniu przepisów zamieszczonych w rozdziałach I i II. Gdyby go nie było, wystarczyłoby najpierw zmienić rozdział XII, by następnie już bez możliwości przeprowadzenia referendum zmienić przepisy rozdziałów I i II.

Do tej pory Konstytucję zmieniono dwukrotnie, choć wielokrotnie podejmowano takie próby. W 2006 r. doszło do zmiany art. 55 Konstytucji ${ }^{8}$. Zmiana ta była związana z koniecznością implementacji decyzji ramowej Rady 2002/584/ WSiSW z 13 czerwca 2002 r. w sprawie europejskiego nakazu aresztowania i procedury wydawania osób między państwami członkowskimi po wstapieniu Polski do UE. Trybunał Konstytucyjny wyrokiem z 27 kwietnia 2007 r. (P 1/059) stwierdził niezgodność art. 607t $§ 1$ ustawy z 6 czerwca 1997 r. Kodeks postępowania karnego w zakresie, w jakim zezwala na przekazanie obywatela polskiego do państwa członkowskiego UE na podstawie europej-

8 Ustawa z 8 września 2006 r. o zmianie Konstytucji Rzeczypospolitej Polskiej (Dz. U. Nr 200, poz. 1471), weszła w życie 7 listopada 2006 r.

9 OTK ZU-A 2005, nr 4, poz. 42. 
skiego nakazu aresztowania, z ówczesną treścią art. 55 ust. 1 Konstytucji. Jednocześnie TK orzekł, że niekonstytucyjny przepis utraci moc z upływem 18 miesięcy od dnia ogłoszenia wyroku w Dzienniku Ustaw. W uzasadnieniu wskazanego wyroku TK wskazał, że „Odroczenie terminu utraty mocy obowiązującej art. $607 \mathrm{t} \S 1$ k.p.k. ma ten skutek, że w okresie 18 miesięcy od ogłoszenia wyroku Trybunału Konstytucyjnego przepis ten (o ile wcześniej nie zostanie uchylony bądź zmieniony przez ustawodawcę), mimo że obalone w stosunku do niego zostało domniemanie konstytucyjności, winien być stosowany przez wymiar sprawiedliwości. Sądy polskie nie mogą więc odmawiać przekazania obywateli polskich ściganych ENA" [europejskim nakazem aresztowania - dop. W.P.]. Po wyroku TK prawodawca, aby dostosować prawo polskie do prawa Unii Europejskiej, zdecydował się na zmianę art. 55 Konstytucji ${ }^{10}$.

Druga zmiana Konstytucji nastapiła w 2009 r. i poległa na dodaniu ust. 3 do art. 99, który ograniczył bierne prawo wyborcze do Sejmu i Senatu ${ }^{11}$. Zgodnie z dodanym przepisem „Wybrana do Sejmu lub do Senatu nie może być osoba skazana prawomocnym wyrokiem na karę pozbawienia wolności za przestępstwo umyślne ścigane $\mathrm{z}$ oskarżenia publicznego". Celem tej zmiany Konstytucji było zatem zapewnienie, by w Sejmie i Senacie nie było osób skazanych prawomocnym wyrokiem na karę pozbawienia wolności za określona kategorię przestępstw.

2. Instytucja prawną mającą zagwarantować w praktyce zasadę nadrzędności Konstytucji jest odpowiedzialność konstytucyjna przed TS $^{12}$. Odpowiedzialność ta obejmuje naruszenie Konstytucji lub ustawy, w związku z zajmowanym stanowiskiem lub w zakresie swojego urzędowania. Odpowiedzialność konstytucyjna przed TS ponoszą: Prezydent, Prezes Rady Ministrów oraz członkowie Rady Ministrów, Prezes Narodowego Banku Polskiego, Prezes Najwyższej Izby Kontroli, członkowie Krajowej Rady Radiofonii i Telewizji, osoby, którym Prezes Rady Ministrów powierzył kierowanie ministerstwem, oraz Naczelny Dowódca Sił Zbrojnych, a ponadto posłowie i senatorowie za naruszenie zakazu prowadzenia działalności gospodarczej z osiaganiem korzyści z majątku Skarbu Państwa lub samorządu terytorialnego i nabywania tego majątku (art. 198 ust. 1 i 2). Doświadczenia z egzekwowaniem odpowiedzialności konstytucyjnej w okresie 20 lat obowiązywania Konstytucji nie uzasadniaja raczej wniosku, że jest to efektywna gwarancja jej nadrzędności. W tym czasie TS zajmował się tylko jedną sprawą i do końca 2017 r. nie rozstrzygną jej, mimo że uchwałę o postawieniu w stan oskarżenia Sejm podją w 2005 r.

${ }_{10}$ Zob. B. Nita-Światłowska, uwagi 26-30 do art. 55, w: M. Safjan, L. Bosek (red.), op. cit., t. 1, s. $1306-1307$.

11 Ustawa z 7 maja 2009 r. o zmianie Konstytucji Rzeczypospolitej Polskiej (Dz. U. Nr 114, poz. 946), weszła w życie 21 października 2009 r.

12 Zob. np. K. Działocha, T. Zalasiński, uwagi do art. 198, w: L. Garlicki (red.), Konstytucja Rzeczypospolitej Polskiej. Komentarz, t. 5, Warszawa 2007, s. 1-16; A. Sakowicz, S. Steinborn, uwagi do art. 198, w: M. Safjan, L. Bosek (red.), op. cit., t. 2, s. 1316-1338. 
3. Jedną z podstawowych gwarancji zasady nadrzędności Konstytucji jest kontrola konstytucyjności prawa przez sąd konstytucyjny ${ }^{13}$. Również Konstytucja Rzeczypospolitej Polskiej przewiduje taka kontrolę przez TK. Trybunał ten jest organem władzy sądowniczej (art. 10 ust. 2), odrębnym i niezależnym od innych władz (art. 173). Podobnie jak sady, TK działa na podstawie sformalizowanych procedur, a niezawisłość sędziego Trybunału jest chroniona podobnie jak niezawisłość sędziów sądów. Do kompetencji TK należy orzekanie w sprawie zgodności norm o niższej mocy prawnej z normami o wyższej mocy prawnej. W praktyce najczęściej wzorcem kontroli są normy konstytucyjne.

Kontrola norm przez TK może mieć charakter prewencyjny albo następczy. Prewencyjną kontrolę norm TK sprawuje wyłącznie z inicjatywy Prezydenta, który może skierować do niego ustawę przed jej podpisaniem lub umowę międzynarodowa przed jej ratyfikacja. Jedynym wzorcem kontroli w tym trybie może być Konstytucja (art. 122 ust. 3 i art. 133 ust. 2). Specyfika prewencyjnej kontroli norm polega na tym, że TK kontroluje normy wyrażone w ustawie albo umowie międzynarodowej w sytuacji, gdy nie sa one jeszcze elementem polskiego systemu prawa. Celem tej kontroli jest niedopuszczenie do wprowadzenia do systemu prawa normy niezgodnej z Konstytucją.

Następcza kontrola norm sprawowana przez TK dotyczy norm, które sa już w polskim systemie prawa, choć wyjątkowo TK może orzekać o normach prawnych nieobowiąujących, jeżeli wydanie orzeczenia w sprawie zainicjowanej skarga konstytucyjna jest konieczne do ochrony konstytucyjnych wolności i praw (art. 59 ust. 3 ustawy z 30 listopada 2016 r. o organizacji i trybie postępowania przed $\mathrm{TK}^{14}$ ).

Orzeczenia TK mają moc powszechnie obowiązujaca i sa ostateczne (art. 190 ust. 1), co oznacza, że są nimi związane wszystkie podmioty prawa i nie przysługują od nich żadne środki zaskarżenia. Cecha ostateczności orzeczeń TK była przedmiotem burzliwych dyskusji w trakcie prac Komisji Konstytucyjnej Zgromadzenia Narodowego. Przeciwnicy ostateczności orzeczeń TK argumentowali, że należy chronić budżet państwa przed skutkami finansowymi rozstrzygnięć sądu konstytucyjnego i wskazywali na konieczność ograniczenia ich ostateczności. Na końcowym etapie prac nad tekstem Konstytucji doprowadzili nawet do wprowadzenia wyjątku od ostateczności orzeczeń TK i wprowadzenia regulacji wzorowanej na unormowaniu z okresu Polski Ludowej, której celem było osłabienie pozycji TK. Na jej podstawie w okresie dwóch lat od dnia wejścia w życie Konstytucji orzeczenia TK o niezgodności z Konstytucją ustaw uchwalonych przed dniem jej wejścia w życie nie były ostateczne i podlegały rozpatrzeniu przez Sejm, który mógł odrzucić orzeczenie TK większością $2 / 3$ głosów w obecności co najmniej połowy ustawowej liczby posłów ${ }^{15}$. Ten wyjątek od ostateczności orzeczeń TK nie dotyczył orzeczeń

${ }^{13}$ Zob. np. Z. Czeszejko-Sochacki, Sqdownictwo konstytucyjne w Polsce na tle porównawczym, Warszawa 2003; L. Garlicki, uwagi do art. 188, w: idem, (red.), op. cit., t. 5, s. 1-31; A. Mączyński, J. Podkowik, uwagi do art. 188, w: M. Safjan, L. Bosek (red.), op. cit., t. 2, s. 1125-1167.

14 Dz. U. poz. 2072.

${ }_{15} \mathrm{Na}$ temat praktyki odrzucania orzeczeń TK przez Sejm zob. L. Garlicki, Odrzucanie orzeczeń Trybunału Konstytucyjnego przez Sejm, w: A. Łopatka, A. Wróbel, S. Kiewlicz (red.), Państwo prawa. Administracja. Sadownictwo. Prace dedykowane Prof. dr. hab. Januszowi Eętowskiemu 
wydanych w następstwie pytań prawnych do TK (art. 239 ust. 1 Konstytucji). Od 17 października 1999 r., a więc po dwóch latach od dnia wejścia w życie Konstytucji, wszystkie orzeczenia TK sa ostateczne.

Konsekwencje orzeczenia o niezgodności danej regulacji z Konstytucją moga być rozpatrywane $\mathrm{w}$ sferze tworzenia i stosowania prawa. W sferze tworzenia prawa norma, o której TK orzekł, że jest niegodna z Konstytucją albo inną normą o wyższej mocy prawnej w wypadku kontroli prewencyjnej nie stanie się elementem polskiego systemu prawa, z kolei w wypadku kontroli następczej zostaje usunięta $\mathrm{z}$ polskiego systemu prawa. W sferze stosowania prawa orzeczenie TK o niezgodności z Konstytucja, umową międzynarodową lub z ustawą aktu normatywnego, na podstawie którego zostało wydane prawomocne orzeczenie sądowe, ostateczna decyzja administracyjna lub rozstrzygnięcie w innych sprawach, stanowi podstawę do wznowienia postępowania, uchylenia decyzji lub innego rozstrzygnięcia na zasadach i w trybie określonych w przepisach właściwych dla danego postępowania (art. 190 ust. 4).

Zgodnie z normą konstytucyjną orzeczenia TK w sprawie kontroli konstytucyjności prawa podlegają niezwłocznemu ogłoszeniu w organie urzędowym, w którym akt normatywny był ogłoszony, a jeżeli akt nie był ogłoszony, orzeczenie ogłasza się w Dzienniku Urzędowym Rzeczypospolitej Polskiej „Monitor Polski” (art. 190 ust. 2).

Trybunał Konstytucyjny w zasadzie bez zakłóceń działał do 2015 r. Sam Trybunał, jak i jego orzeczenia cieszyły się dużym autorytetem nie tylko w Polsce, ale również poza jej granicami. Niestety w następstwie uchwalania w 2015 i 2016 r. kolejnych ustaw regulujących organizacje oraz tryb postępowania przed TK, wydarzeń związanych z wyborem przez Sejm sędziów TK, odmowy przyjęcia od niektórych z nich ślubowania przez Prezydenta, nieogłaszania orzeczeń TK, zarzutów działania przez TK niezgodnie z prawem, a także kampanią dezawuującą sędziów i pracowników TK oraz samą instytucję, mamy do czynienia z sytuacją głębokiego kryzysu konstytucyjnego, który stał się przedmiotem zainteresowania Rady Europy i organów UE: Komisji Europejskiej i Parlamentu Europejskiego.

4. Kolejną gwarancją zasady nadrzędności Konstytucji, którą przewidziano w jej przepisach, jest jej bezpośrednie stosowanie. Zgodnie z art. 8 ust. 2 Konstytucji: „Przepisy Konstytucji stosuje się bezpośrednio, chyba że Konstytucja stanowi inaczej”. Interpretacja tego przepisu wzbudza spory ${ }^{16}$. Niemniej

w 60. rocznice urodzin, Warszawa 1999, s. 281-293; C. Bakalarski, Orzeczenia Trybunału Konstytucyjnego oddalone przez Sejm, w: F. Rymarz, A. Jankiewicz (red.), Trybunat Konstytucyjny. Księga XV-lecia, Warszawa 2001, s. 13-21; M. Florczak-Wątor, Orzeczenia Trybunału Konstytucyjnego $i$ ich skutki prawne, Poznań 2006, s. 52-54.

${ }^{16}$ Zob. np. L. Garlicki, Bezpośrednie stosowanie Konstytucji, w: Konferencja naukowa: Konstytucja RP w praktyce, Warszawa 1999, s. 12-32; A. Maczyński, Bezpośrednie stosowanie Konstytucji przez sqdy, „Państwo i Prawo” 2000, z. 5, s. 3-14; S. Wronkowska, W sprawie bezpośredniego stosowania Konstytucji, „Państwo i Prawo” 2001, z. 9, s. 3-23; B. Nita, Bezpośrednie stosowanie Konstytucji a rola sqdów w ochronie konstytucyjności prawa, „Państwo i Prawo” 2002, z. 9, s. 3646; K. Działocha, uwagi do art. 8, w: L. Garlicki, M. Zubik (red.), op. cit., t. 1, s. 300-323; P. Tuleja, uwagi do art. 8, w: M. Safjan, L. Bosek (red.), op. cit., t. 1, s. 319-325. 
jednak nie wzbudza kontrowersji, że bezpośrednie stosowanie przepisów Konstytucji może przejawiać się w: 1) stosowaniu normy konstytucyjnej jako samoistnej podstawy określonego rozstrzygnięcia, 2) współstosowaniu norm konstytucyjnych i norm o niższej mocy prawnej. W ten sposób bezpośrednio stosują normy konstytucyjne zarówno organy tworzące prawo, jak i stosujace prawo, w szczególności sądy.

Bezpośrednie stosowanie przepisów Konstytucji podkreśla, że Konstytucja nie jest tylko pięknie brzmiącą deklaracja, jak być powinno, ale wyraża normy prawne, które wiążą sprawujących władzę - wszystkie organy władzy publicznej. W odniesieniu do klasycznych organów państwa oznacza to, że: władza ustawodawcza ma stanowić prawo, władza wykonawcza ma je wykonywać, władza sądownicza zaś rozstrzygać spory związane z tym prawem. Wszystkie z tych władz, wykonujac swoje kompetencje powierzone im przez Konstytucję, mają obowiązek działać zgodne z normami konstytucyjnymi wyznaczającymi, jak postępować, i determinującymi treść aktów prawnych będących rezultatami określonych czynności, np. aktów normatywnych czy orzeczeń sądowych.

Trudno o jednoznaczną ocenę, czy w okresie 20 lat obowiązywania Konstytucji bezpośrednie stosowanie jej przepisów upowszechniło się, czy też z trudem torowało sobie drogę. Wszakże nawet stanowienie ustaw przewidzianych wprost w Konstytucji zakończyło się dopiero 6 września 2015 r., gdy weszła w życie ustawa z 11 lipca 2014 r. o petycjach ${ }^{17}$, nie wspominajac o problemach sądów niższych instancji, w praktyce najważniejszych, gdyż rozstrzygających największą ilość spraw i z którymi pierwszy kontakt mają obywatele domagający się sprawiedliwości.

5. Wśród gwarancji zasady nadrzędności Konstytucji należy wspomnieć również o słowach ślubowania posłów i senatorów oraz przysiag składanych przez Prezydenta i członków Rady Ministrów. Otóż posłowie i senatorowie przed rozpoczęciem sprawowania mandatu ślubuja „przestrzegać Konstytucji i innych praw Rzeczypospolitej Polskiej" (art. 104 ust. 2). Prezydent Rzeczypospolitej przed objęciem urzędu przysięga, że dochowa „wierności postanowieniom Konstytucji” (art. 130). Z kolei Prezes Rady Ministrów, wiceprezesi Rady Ministrów i ministrowie, obejmując swoje urzędy, przysięgają dochować „wierności postanowieniom Konstytucji i innym prawom Rzeczypospolitej Polskiej”. Po ślubowaniu czy przysiędze osoby obejmujące wskazane urzędy mogą dodać zdanie „Tak mi dopomóż Bóg” i w praktyce większość osób zwraca się do Boga.

Roty wskazanych ślubowań i przysiag moga budzić spory wśród prawników związane z tym, czy wypowiedzi te wyrażają normy prawne czy też nie. Nie budzi jednak wątpliwości, że podkreślają one obowiązek przestrzegania Konstytucji wyrażony w normach konstytucyjnych majacych range zasad prawa: państwa prawa (art. 2) i legalizmu (art. 7). Co można zatem myśleć o osobach, które doprowadziły do uchwalenia ustawy, której projekt zawierał przepisy w oczywisty sposób niezgodne z Konstytucja, co potwierdzały opinie takich gremiów, jak: Sąd Najwyższy, Krajowa Rada Sądownictwa, Krajowa

17 Dz. U. 2017, poz. 1123. Zgodnie z art. 63 zd. 2 Konstytucji: „Tryb rozpatrywania petycji, wniosków i skarg określa ustawa”. 
Izba Radców Prawnych, Naczelna Rada Adwokacka, eksperci powołani przez komisję sejmową i Biuro Legislacyjne Senatu? Opinie te były i są powszechnie dostępne na stronie internetowej Sejmu, przedstawione w nich konkluzje sa jednoznaczne i bezsporne, a mimo to ustawa została uchwalona wraz z niezgodnymi z Konstytucją przepisami, podpisana przez Prezydenta i ogłoszona w Dzienniku Ustaw ${ }^{18}$.

IV. Można zatem zasadnie postawić pytanie: czy istnieją prawne gwarancje, które skutecznie i trwale zapewnią nadrzędność Konstytucji? Moim zdaniem takich gwarancji nie ma. W szczególności gwarancją taką nie jest prawo do oporu przeciwko temu, kto usiłuje obalić porządek konstytucyjny ${ }^{19}$. Co najwyżej prawo do oporu legitymuje sprzeciw społeczeństwa w takiej sytuacji, a o skuteczności tej instytucji przesądzi w ostatecznym rachunku siła tych, którzy porządek konstytucyjny usiłuja obalić. Czy zatem jesteśmy zupełnie bezradni w staraniach o zapewnienie Konstytucji nadrzędności? Otóż nie, nie jesteśmy. Pomóc może nam odpowiedni poziom kultury prawnej, w szczególności kultury konstytucyjnej. To od niej przede wszystkim zależy, czy Konstytucja będzie przestrzegana. Prawne gwarancje zasady nadrzędności Konstytucji, choć ważne, to muszą opierać się na głębokim przeświadczeniu, że naruszanie norm konstytucyjnych jest zawsze złe, ponieważ prowadzi do zwycięstwa polityki nad prawem. W praktyce grupa polityków sprawujących władzę i ich poplecznicy arbitralnie wyznaczają społeczeństwu, jak ma myśleć i co ma robić. $Z$ tego powodu warto podjąć trud przekonywania, że Konstytucja jest najwyższym prawem Rzeczypospolitej Polskiej, a jej przestrzeganie ma na celu zachowanie przyrodzonej godności człowieka, jego prawa do wolności i obowiązku solidarności z innymi.

dr Witold Ptowiec

Uniwersytet im. Adama Mickiewicza w Poznaniu

plowiec@amu.edu.pl

\section{GUARANTEES OF THE PRINCIPLE OF THE SUPREMACY OF THE CONSTITUTION}

Summary

The principle of the supremacy of the Constitution requires implementation of constitutional norms (positive aspect) and prohibits behaviours that are inconsistent with constitutional norms (the negative aspect). The legislator is therefore obliged to create sub-constitutional norms in such a way that they comply with constitutional norms and ensure that they are implemented as fully as possible. Similarly, with regard to the application of the law, decisions taken on the

18 Chodzi o ustawę z 22 lipca 2016 r. o Trybunale Konstytucyjnym (Dz. U. poz. 1157 ze zm.). Projekt tej ustawy (druk nr 558) wraz z wymienionymi opiniami dostępny jest na stronie internetowej Sejmu <http://www.sejm.gov.pl/Sejm8.nsf/PrzebiegProc.xsp?nr=558> [dostęp: 10.01.2017].

19 Prawo do oporu przewiduje art. 20 ust. 4 Ustawy zasadniczej Republiki Federalnej Niemiec z 23 maja 1949 r. (BGBl. I, s. 1), zgodnie z którym: „Wobec każdego, kto usiłuje obalić ten porządek, wszyscy Niemcy mają prawo oporu, jeśli inne przeciwdziałanie nie jest możliwe”. Przepis ten został dodany ustawą z 24 czerwca 1968 r. (BGBl. I, s. 709). 
basis of the Constitution must comply with its norms and implement these norms as effectively as possible. The actual assurance of the principle of the supremacy of the Constitution is important for the protection of the citizen from the state, because the Constitution as a social contract sets out absolute limits for the authorities that must not be trespassed. The Constitution contains numerous guarantees of its supremacy. They include in particular: the procedure for amending the Constitution, liability to the Tribunal of State, control of the constitutionality of the law by the Constitutional Tribunal, direct application of the Constitution by courts and swearing an oath by members of parliament, the President and members of the Council of Ministers. However, there are no legal guarantees which would effectively and permanently guarantee the supremacy of the Constitution. In an effort to ensure that the Constitution takes precedence, an appropriate level of legal culture must be ensured. 
